\title{
Construction of humanized management model of College
}

\section{Textbooks}

\author{
Genlian Zhang ${ }^{1, a}$ \\ ${ }^{1}$ Jilin business and technology college , Jilin, China \\ a24683708@qq.com
}

\begin{abstract}
Teaching material management is an important part of teaching management in Colleges and universities. It has been ten years since colleges and universities have implemented the complete credit system. It is necessary to construct a new model of teaching material management for facing the new situation. Teaching materials management should be consistent with the current educational philosophy. The management mode of rigid compulsion turns to human nature and service management mode. We set up a new concept of teaching material management as a service to improve the awareness of public management and improve the management ability of the public.
\end{abstract}

Key word: Humanization, teaching material management, management information

With the implementation of reform measures, such as college enrollment expansion, credit system, self-enrollment, professional and general education, the management of college teaching materials becomes more and more complicated. According to the new situation and new problems in the teaching material management, this paper expounds some viewpoints. This paper expounds the humanized management mode, which is the starting point and standpoint of the teaching material management in Colleges and universities. It is the key to solve a series of problems in the current teaching materials.

\section{Analysis on the environment and present situation of teaching material management}

The popularization of higher education in our country, the increase of the scale of running a school, the increase of the level of running a school, the rich form of running a school, the implementation of the credit system, make the management of the teaching material become complicated[1]. Uncertainties and other factors were the increase in the types of teaching materials and students choose a larger span which led to the use of teaching materials. There are some problems in teaching material management at present.

\subsection{Personnel quality problem}

The teaching material management personnel status quo, many colleges and universities teaching management personnel education is generally not high. The teaching staff's work achievement cannot be evaluated objectively. They lack the opportunity of further training, and their quality is hard to be further improved. Such a management team is difficult to adapt to the needs of the reform and development of 
higher education.

\subsection{Information problem}

The amount of information, workload, and timeliness and so on are improved. The original teaching materials management means can't meet the needs of modern educational reform and development. The school management mode is uneven, some good and some bad. Some schools still stay in the traditional manual management mode. After the implementation of the credit system, it is very difficult to obtain the ordering data accurately. Order quantity depends on the student textbook selection results, but due to the uncertainty of the course teaching departments cannot get timely complete and accurate materials subscription plan.

\subsection{Textbook quality problem}

The rapid development of science and technology has led to the acceleration of teaching materials, especially in the fields of computer science and technology, biotechnology and other fields. The level of professional teaching materials was generally not high or lack of systematic teaching materials when Cross disciplinary and emerging professionals continued to emerge. Colleges and universities must grasp the trend of the innovation and development of teaching materials, and actively support the independent innovation, integrated innovation, the introduction of textbooks and the teaching material renewal plan.

\subsection{Supply and distribution of textbooks}

The uncertainty of the course directly leads to the uncertainty of the number of courses. Textbook ordering cycle is generally longer, before class cannot implement the teaching material. After the implementation of the credit system, the issuance of teaching materials according to the serial number of courses caused many students cannot get the book. The students who are enrolled in the course serial number cannot ensure that the representative of each course serial number is sent to each student.

2. the humanized management of college teaching materials

School-based management referred to as "ISM". It was launched in the United States and most developed countries in the late 1970s[2]. The essence of school-based management is to take the school as the main body, the development as the subject, and the human as the main body. The teaching material management is in the school management system and teaching management system[3]. The elements of the teaching material management subsystem and the teaching material management system are the active factors of school based management. In this paper, the humanized teaching material management mode is in line with the current "school-based management" education concept.

2.1 The routine management of teaching materials based on Humanized Management

The basic elements of management activities are composed of management subject, management object, management purpose, management function and method, management environment and so on. The main body of management is the decisive factor in management activities. All the management functions must play a role through the management. Individual managers or group management institutions can only be borne by the people, and the quality and ability of these people directly 
determine the effectiveness and efficiency of management. The goal of modern management is not to get the maximum benefit, the highest efficiency and has been turned to the all-round development of people. Management functions, methods and management environment must be developed, created and controlled by the people or implemented. This fully explains the decisive role of human in management practice. Humanized management is a kind of management mode which takes full attention to human factors in the whole process of management, and deeply excavates the potential of human beings. "Humanized management" is a new management concept evolved from modern behavioral science. Humanized management is a kind of management method, which is based on people's life and work habits, so that management can be more close to human nature, so as to achieve a reasonable and effective way to improve people's work potential and high work efficiency. As the main body of knowledge and wisdom, people have become more and more important, and the development of human potential has become an important issue of modern management. The key is to strengthen the establishment of people-oriented management philosophy in practical work, focusing on humane care. Specifically, it is the implementation of Teacher centered, student centered management concept, the relationship between improving the quality of management personnel, good management personnel and the teaching secretary, to meet the needs of teachers and students, mobilize the management staff initiative, enthusiasm and creativity of the work in the first place. The practice of "humanization" management philosophy provides a detailed textbook subscription list for teachers. It can provide excellent teaching materials to promote the newly published book, provide convenience for teachers to adopt teaching materials; the research and development of materials management system, teachers and students through the campus network query the use of teaching materials; students can query the individual textbooks; students have the right to choose whether to subscribe to the textbook.

2.2 The requirements of the quality of the teaching staff based on the humanized management

The main contents of the teaching material management personnel include the teaching material construction, research, selection and supply and so on. The function of the teaching staff in the construction of teaching materials in Colleges and universities can be summarized as communication, coordination, publicity and consultation. After the implementation of the credit system teaching management, the teaching material has a straight line. The teaching staff should enhance their sense of responsibility and improve their professional level. The construction, research and management of the teaching materials of the university put forward scientific and reasonable constructive suggestions. We should implement the microcomputer and network management of teaching materials. As soon as possible skilled operation of the computer and the corresponding network management platform, so that the teaching materials out of storage, statistics, query, storage, and other operations quickly completed. Strengthening the construction of teaching material management team can realize the transformation of functions. The construction of teaching material management team includes organization construction and quality 
construction.

2.3 Requirements of teaching material information system based on Humanized Management

With the deepening of the reform of higher education, the traditional teaching material management mode has been challenged. The rapid development of the computer network technology and the construction of the network platform of the press are the conditions of the network management of the teaching materials in Colleges and universities. The teaching materials management departments of all colleges and universities should actively use the network technology to establish the network platform of teaching material management. Through the network platform, the teaching material management personnel can understand the new development of the national higher education, and clear the supply of teaching materials of various publishers and Xinhua bookstore. Through the network platform to collect teaching materials evaluation information, research information; through the network platform to help teaching staff to establish teaching materials planning, teaching materials statistics, teaching materials storage management, teaching materials, etc.

2.4On the quality of teaching materials based on humanistic management

Strengthen the selection of management, strict selection process is to put an end to the random and subjective assumptions in the selection of materials to ensure the advanced nature of teaching materials and applicability. This work should be done in the following aspects.The selection of teaching materials should improve the quality of teaching and enhance the quality consciousness. The courses offered are of high quality. Correctly handle the relationship between the selection of national recommended teaching materials and the teaching materials[4].

3. Teaching materials research

Textbooks are open tender procurement, reduce intermediate links. The teaching material "flat out into the flat" policy was carried out. Textbooks are open tender procurement, reduce intermediate links. The teaching material "flat out into the flat" policy was carried out. Achieve the purchase of new materials Zero Inventory Through the supplier quality service commitment and internal management and other ways, reduce or avoid the backlog of waste materials[5]. The new mode of teaching materials include: purchase of several books and network purchase system. This can provide teachers with more convenient and humane service.

The humanization of college teaching material management is a new management model in summary. Under the concept of school based management, the teaching material management department should fully understand the role of teaching materials in higher education reform. In accordance with the basic requirements of "human nature" management, work should have new ideas, new initiatives, new breakthroughs, and new situation. Teaching material management should be full of creativity. Humanized teaching material management system in Colleges and universities can promote the development of teaching materials management in Colleges and universities. 


\section{Reference}

[1] Ling-Zhu W U, Wang S, Cai Z Q. A Study on the Credit System of Colleges and Universities, Textbook Accounting and Management[J]. Journal of Jiaxing College, 2005.

[2] Cheng Y C. School effectiveness and school-based management : a mechanism for development[J]. Routledge, 1996, 7(1):35-61.

[3] Grauwe A D. Improving the Quality of Education Through School-Based Management: Learning From International Experiences[J]. International Review of Education, 2005, 51(4):269-287.

[4] Lu Shaojuan. The teaching material management in Colleges and Universities under the credit system[J]. Tianjin Agricultural University Reported, 2007 (11): 68-69.

[5] Dengbo. On the main external relations of university teaching material management department[J]. Education (Higher Education Forum), 2016 (09): 34-35. 